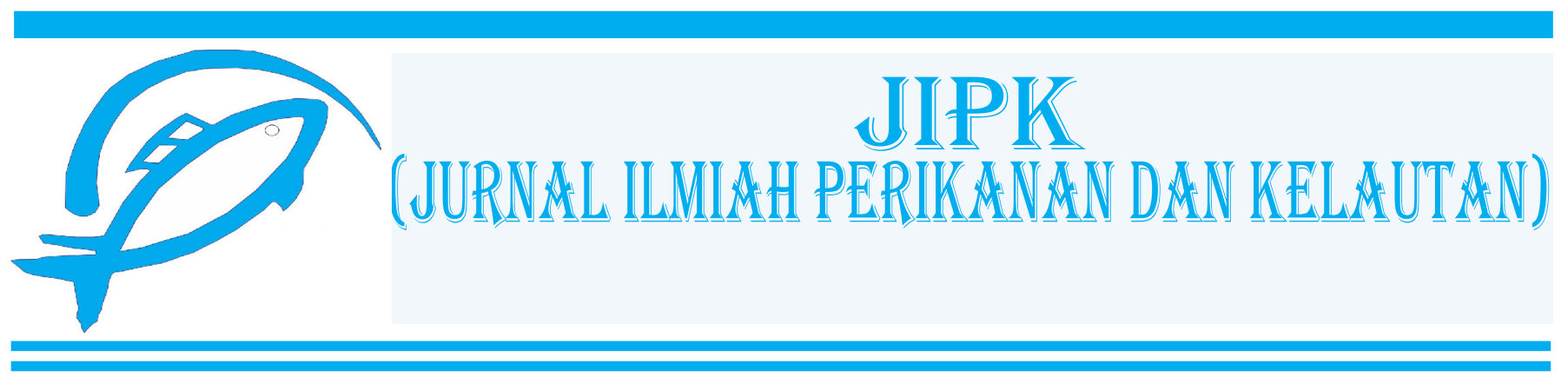

Research Article

\title{
Correlation of Nitrite and Ammonia Concentration with Prevalence of Enterocytozoon hepatopenaei (EHP) in Shrimp (Litopenaeus vannamei) on Several Super-intensive Ponds in East Java, Indonesia
}

\author{
Anord Charles Nkuba ${ }^{1,5}$, Gunanti Mahasri ${ }^{(D)}$, Nunuk Dyah Retno Lastutiª, and Adamu Ayubu \\ Mwendolwa ${ }^{4}$ \\ ${ }^{1}$ Study program Fisheries and Marine Biotechnology, Faculty of Fisheries and Marine, Universitas Airlangga, Surabaya, East \\ Java, 60115. Indonesia. \\ ${ }^{2}$ Department of Fish Health Management and Aquaculture, Universitas Airlangga, Surabaya, East Java, 60115. Indonesia. \\ ${ }^{3}$ Department of Parasitology, Faculty of Veterinary Medicine, Universitas Airlangga, Surabaya, East Java, 60115. Indonesia. \\ ${ }^{4}$ Department of Biological Science, College of Education, Mkwawa University, MUCE, 2513. Tanzania. \\ ${ }^{5}$ Aqua-farms organization, Sinza C, Dar es Salaam, 22564. Tanzania.
}

\section{OPEN $O$ ACCESS}

\section{ARTICLE INFO}

Received: January 06, 2021

Accepted: March 05, 2021

Published: March 31, 2021

*) Corresponding author:

E-mail: mahasritot@gmail.com

Keywords:

Hepatopancreas

DNA

PCR

Water physicochemical parameters.

This is an open access article under the CC BY-NC-ND license (http://creativecommons.org/licenses/by-nc-nd/4.0/)

\begin{abstract}
Enterocytozoon hepatopenaei (EHP), a microsporidia parasite known to hinder shrimp growth by infecting its hepatopancreas, is recently an emerging infection for Litopenaeus vannamei farms in Indonesia. The present study was conducted to investigate the relationship between nitrite and ammonia concentration with EHP infection in the super-intensive ponds. Shrimps and water samples were collected from six ponds in aquaculture super-intensive ponds with a stocking density of 5,000 shrimps in each pond which is located in Pasuruan, Lamongan, and Tuban Regency, Indonesia. The water sample was taken to the laboratory for the measurement of ammonia and nitrite. The samples of ammonia and nitrite were detected by spectrophotometer, and the PCR was used to detect 18S rRNA of EHP. The PCR analysis that showed two positive samples of $L$. vannamei, from the ponds with a high concentration of ammonia and nitrite, were infected by EHP. The statistical analysis showed a significant correlation between ammonia and nitrite with the prevalence of EHP infections, where the Pearson correlation (r) was 0.980 and 0.943 , respectively. There was a high prevalence of EHP infection with the increase in nitrite concentration and ammonia in pond four and pond six. The concentration of over $1 \mathrm{mg} / \mathrm{l}$ of ammonia and nitrite could influence EHP infection prevalence in the shrimp farms.
\end{abstract}

Cite this as: Nkuba, A. C., Mahasri, G., Lastuti, N. D. R., \& Mwendolwa, A. A. (2021). Correlation of Nitrite and Ammonia Concentration with Prevalence of Enterocytozoon hepatopenaei (EHP) in Shrimp (Litopenaeus vannamei) on Several Super-intensive Ponds in East Java, Indonesia. Jurnal Ilmiah Perikanan dan Kelautan, 13(1):58-67. http://doi.org/10.20473/jipk.v13i1.24430 


\section{Introduction}

Shrimp farming in Indonesia has increased dramatically in the past decade to export between 220,000 and 260,000 tons in 2018. A total of $60 \%$, $19 \%$, and $5 \%$ of shrimp production were shipped to the United States of America, Japan, and the European Union, respectively. Furthermore, among the shrimp exported in 2018, around $80 \%$ was L. vannamei (Rubel et al., 2019). In 2001, Indonesia officially introduced $L$. vannamei as the primary culture species to replace the previous Penaeus monodon (Hanggono et al., 2019). The former native $P$. monodon declined because of the abrupt eruption of diseases such as white spot disease. $L$. vannamei has advantages over $P$. monodon due to its fast growth and high resistance to diseases (Mahasri et al., 2019), it can be cultured in high stocking density, it has a high selected viral-pathogen-free domesticated broodstock supply, lower demand for dietary protein, more effective use of plant proteins in formulated diets, greater adaptability to low salinity, better tolerance to ammonia and nitrite toxicity, and high larval survival and lower susceptibility to formulated diets (Biju et al., 2016; Liao and Chien, 2011). Despite the mentioned advantages of culturing $L$. vannamei, during the past few years, the emergency of microsporidians pathogen E. hepatopenaei (EHP) in Indonesia and other countries such as Thailand, China, Malaysia, Vietnam, and India has been reported (Caro et al., 2020; Sivakumar et al., 2018; Biju et al., 2016; Rajendran et al., 2016) which infects the hepatopancreases of the shrimp and causes low growth, chronic infection, and mortalities.

$E$. hepatopenaei is the fungal obligate intracellular microsporidia parasite (Tourtip et al., 2009). Previous studies reported that EHP can slough off the cells in the hepatopancreas of tiger shrimp and white leg shrimp (Hanggono et al., 2019; Aranguren et al., 2017). EHP is associated with severe growth retardation in shrimps (Rajendran et al., 2016) and yields a meager harvest. They proliferate in the shrimp's hepatopancreas and midgut, mature spore then spread out from the faces ready to infect other shrimps. EHP infects the hepatopancreases by sloughing the cells, which impacts reduction in feeding practice, less appetite, and causes slow growth (Tang et al., 2017; Jaroenlak et al., 2016). Previous studies showed that EHP is associated with white feces syndrome (WFS) which appeared floating on the surface of the shrimp's ponds (Caro et al., 2020; Anjaini et al., 2018; Tang et al., 2016). On the contrary, Alfiansah et al., (2020), Sumini and Kusdarwati (2020) reported that WFS is caused by bacteria such as Alteromonas and Pseudoalteromonas sp. due to the presence of a high number of mentioned bacterial cells in the fecal matter of the shrimps. The associated EHP signs include the slow growth between the shrimp stocked in the same period. Other gross symptoms include the appearance of a whitish hindgut and loose carapace (Tang et al., 2016). EHP can be transmitted mainly orally by ingestion of infected live feeds such as brine shrimp Artemia salina, polychaetes, and mollusks (Karthikeyan and Sudhakaran, 2020; Kesavan and Sudhakaran, 2019).

The previous studies stated that ammonia and nitrite are stress factors in aquaculture. High stocking density and poor management account for the stress factors that lead to a weak immune system (Pamenang et al., 2020). The exposure of ammonia and nitrite results in increases the risk of pathogens emergence (Han et al., 2017; Liu and Chen, 2004). According to Liu et al. (2020), there is a decrease in immune cell counts, the ratio of apoptotic cell increase, and so affect the immunity of the shrimp under ammonia exposure. Other study showed that water quality correlates with the growth of pathogen that affects the development of L. vannamei, such as Acineta sp., Epistylis sp., Nematopsis sp., and Leucothrix mucor (Gutiérrez-Salazar et al., 2011). It was reported that a high concentration of ammonia and nitrite exposure to shrimp can damage intestine barriers mucosal which act as shrimp defenses tissue against pathogens (Duan et al., 2018). In the ponds, shrimps themselves act as a source of ammonia as they tend to release nitrogenous wastes as the end products of protein catabolism (Liu and Chen, 2004). Also, excess feeds and decomposition of organic matter accumulate in the ponds add up to the ammonia concentration in the water. Zhao et al. (2020) stated that the intolerable concentration of ammonia and nitrite inhibits innate immune factors such as phenoloxidase and antimicrobial activities. It also impairs the expression of chitinase enzymes and hence interferes with molting which reduces the growth rate of the shrimps. Liu and Chen (2004) reported that $5.24 \mathrm{mg} \mathrm{l}^{-1}$ ammonia-N was able to reduce the phenoloxidase activity after one week, which can account for the emergence of the EHP in the super-intensive ponds. The study also concluded that the high ammonia concentration led to depression in the immune which resulted in the emergence of pathogenic diseases. An intensive aquaculture system is essential to maintain and manage water quality parameters including ammonia and nitrite. Due to high stocking density of super-intensive ponds, which is above 250 shrimps per $\mathrm{m}^{3}$ (Nguyen et al., 2019), super-intensive pond requires intensive care of ammonia and nitrite to prevent the emergence of pathogenic diseases including EHP.

There was no study addressing nitrite and ammonia 


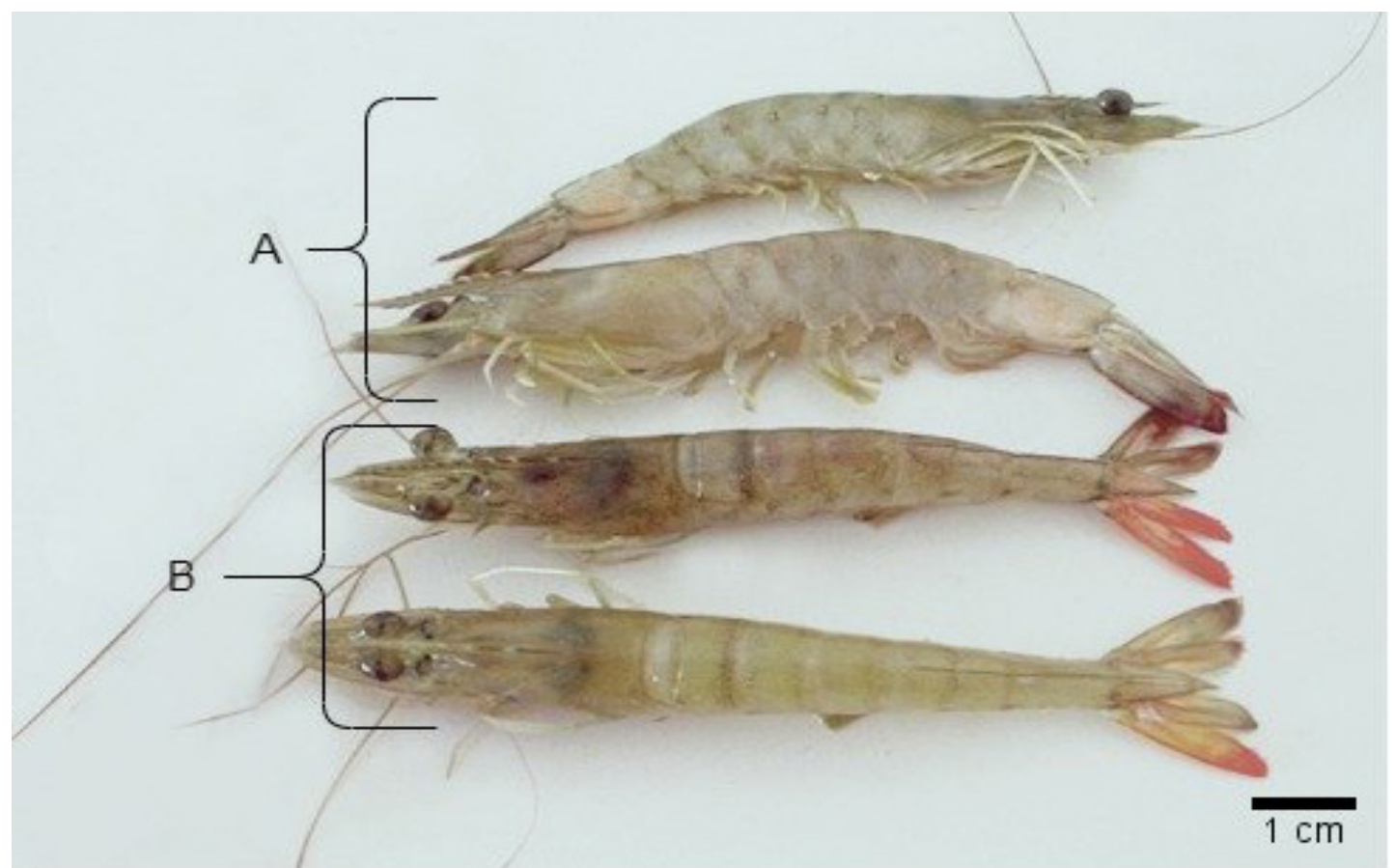

Figure 1. Visual observation of Litopenaeus vannamei obtained during the sample collection from the shrimp's pond farms. A pale white, contracted, and shortened hepatopancreases of EHP infected shrimp in group A. In group B, the shrimp appeared to be large size compared to group A with normal hepatopancreases.

concentration with EHP infection in L. vannamei in super-intensive ponds. Thus, this study was conducted to investigate nitrite and ammonia's correlation in influencing EHP infection in super-intensive ponds.

\section{Materials and Methods}

\subsection{Study area}

The samples were collected randomly from six ponds located in Pasuruan, Lamongan, and Tuban Regency East Java, Indonesia, with two ponds in each regency. In this study, a total of 36 shrimps were enough to provide the relationship of each pond with the prevalence of EHP infection. Physicochemical water parameters and EHP diagnosis were made at the Center for Brackish Water Cultivation Fisheries laboratory, located at Jepara Indonesia.

\subsection{Sample collection and sample size}

Six samples of shrimp from six different shrimp ponds stocked in the same period were collected for diagnosis of EHP, making a total of thirty-six samples. The samples were collected according to Standar Nasional Indonesia SNI (2000) and the stocking density was estimated to be 5,000 shrimps on each pond. After a randomized collection of the sample they were categorized based on the degree of infection, from mild infected, mid-infected, and highly infected shrimps. The live sample was then supplied with an aerator and dry ice for transport to the laboratory.

\subsection{DNA extraction, PCR amplification}

The DNA was extracted from the hepatopancreas of the shrimp sample. Twenty-five milligram of obtained hepatopancreas samples was then grinded and then mixed with $500 \mu \mathrm{L}$ of lysis buffer $(50 \mathrm{mM}$ Tris, $1 \mathrm{~m}$ Methylene diamine tetra-acetic acid (EDTA), 500 $\mathrm{mM} \mathrm{NaCl}, 1 \% \mathrm{SDS}$ ), and $0.1 \mathrm{mg}$ proteinase, then, the mixture was centrifuged for $10 \mathrm{~min}$ at $4^{\circ} \mathrm{C}$. Ethanol was added to the supernatant kept at $-20^{\circ} \mathrm{C}$ for one hour and then centrifuged for $10 \mathrm{~min}$ at $4^{\circ} \mathrm{C}$. The extracted DNA pellet was washed with alcohol and re-suspended in nuclease-Free water (Thermo Fisher Scientific).

The amplification was done by PCR using forward and backward primers. The primer was designed according to Hanggono et al., (2019) with a pair of primer (MF1-5'- CCGGAGAGGGAGCCTGAGA -3'and MR1-5'- GACGGGCGGTGTGTACAAA -3'). The reaction was done in a thermocycler (Eppendorf, USA). Denaturation was at $94^{\circ} \mathrm{C}$ for $20 \mathrm{sec}$ followed by annealing at $55^{\circ} \mathrm{C}$ for $30 \mathrm{sec}$, and extension was done at $72^{\circ} \mathrm{C}$ for $5 \mathrm{~min}$. The amplified products were then visualized in the $2 \%$ agarose gel.

\subsection{Physicochemical parameters of the water}

Physicochemical water parameters $(\mathrm{pH}$, salinity, nitrate, nitrite, ammonia temperature, and dissolved oxygen) were measured. Nitrite and ammonia data were taken for analysis of the relationship with the EHP 
infection in shrimp culture. Water sampling was done from each fish pond. The samples collected were used for the analysis of physicochemical water parameters. $\mathrm{pH}$ meter, mercury-filled thermometer with ranges from $0^{\circ} \mathrm{C}$ to $100^{\circ} \mathrm{C}$, refractometer, and DO meter were used to measure $\mathrm{pH}$, temperature, salinity, and dissolved oxygen respectively in situ. The water sample of 1,500 $\mathrm{ml}$ was taken using a water sampler and then preserved with pieces of ice in the cool box to limit chemical and biological activities. Furthermore, the water sample was transported to the laboratory for analysis. Ammonia was determined by using a spectrophotometer (Zitomer and Lambert, 1962), nitrate was determined by simple heterogeneous reduction followed by spectrophotometer (Morris and Riley, 1963), and nitrite was also done by spectrophotometric determination (Aydin et al., 2005).

\subsection{Data analysis}

Statistical analysis was performed with SPSS (ver. 26, IL, USA). Pearson correlation (r) and simple linear regression were used to analyze the relationship between the variables. The prevalence of diseases was calculated by the following formula:

Number of EHP infected shrimp $\times 100=$ Prevalence $(\%)$ Total number of a sample shrimp

\section{Results and Discussion}

\subsection{PCR amplification analysis.}

The sampled shrimps hepatopancreas PCR amplification results targeting the designed small subunit 18S rRNA (ssu rRNA) were analyzed. The PCR amplification results showed a product size of 510 bp from the two samples (Figure 2 A, B). Litopenaeus vannamei was collected from the six ponds in three different East Java regions (Pasuruan regency, Lamongan regency, and Tuban regency) two samples were found to be positive for EHP out of the 36 samples of Juvenile. The sequence analysis by BLAST search of $18 \mathrm{~S}$ rRNA of EHP showed $99 \%$ similarity to the 18S rRNA gene of EHP from India (GenBank MH260592.1). Rajendran et al. (2016) showed $86 \%$ to $100 \%$ similarities of EHP from India with those obtained in Vietnam and Thailand.

When the samples were observed and compared, they were observed to be small compared to other shrimps stocked in the same period and with fewer clinical signs (Figure 1). The use of specific detection method such as PCR, LAMP, In-situ hybridization (ISH), histological examination of hepatopancreas is necessary to diagnose the EHP pathogens due to their less noticeable clinical signs (Hanggono et al., 2019; Rajendran et al., 2016; Jaroenlak et al., 2016; Tang et al., 2015; Tourtip et al., 2009). It is tough to notice the EHP infected shrimps by using naked eyes except with high experience in observing EHP infection. Therefore, a highly sensitive detection method is suggested (Tang et al., 2015).
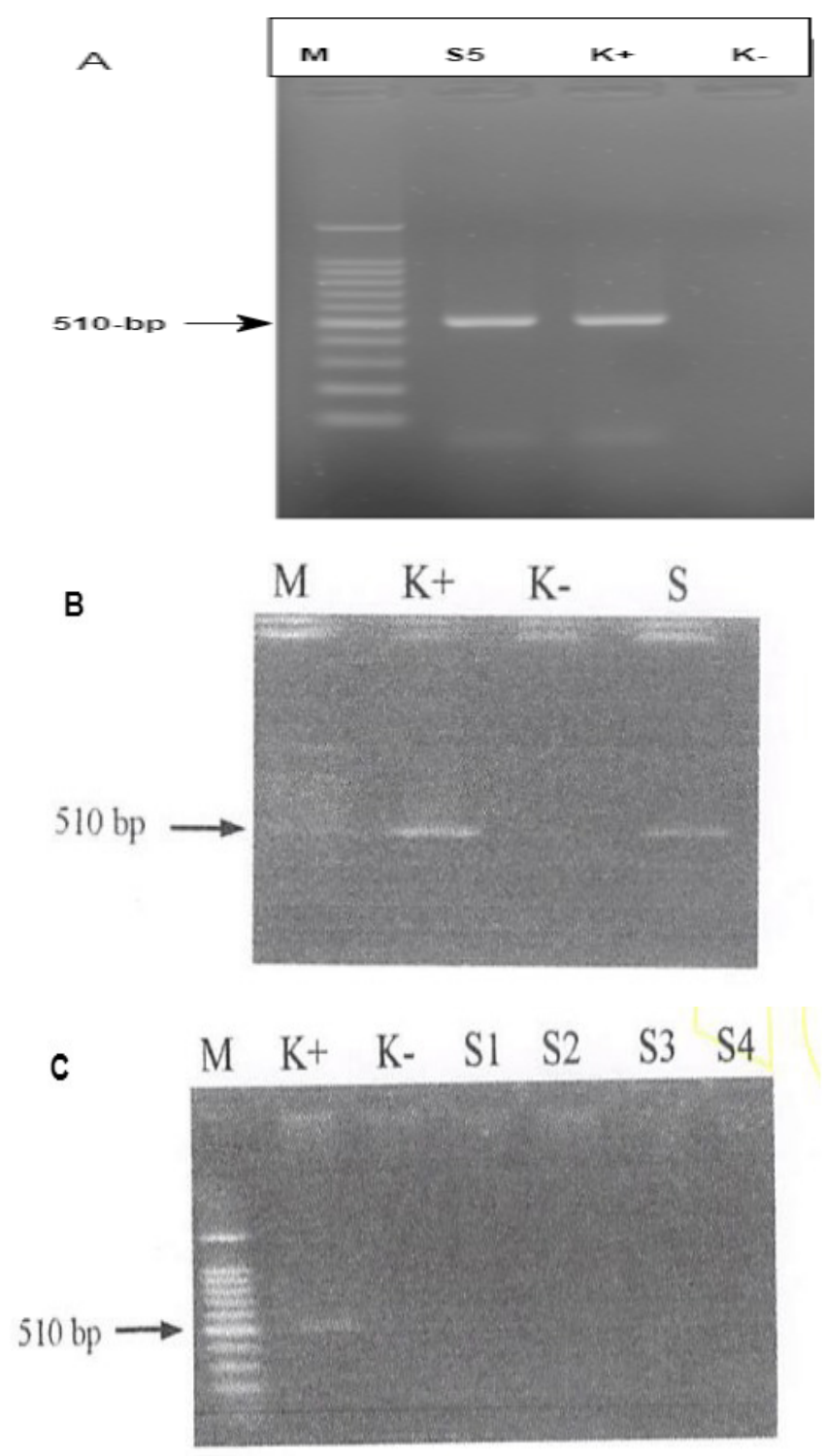

Figure 2. A \& B. PCR detection analysis results showed $18 \mathrm{~S}$ rRNA from Litopenaeus vannamei hepatopancreas tissue sample. A PCR product size of 510-bp was obtained. $\mathrm{S}$ and 55 showed a positive EHP test from pond 4 and pond 6 respectively. C. PCR products showed negative EHP detection in the S1, S2, S3, and S4 hepatopancreas tissue samples. Note - M (100-bp) - marker, S, S1, S2, S3, S4, S5 are the shrimp hepatopancreas tissue samples from other ponds, and $\mathrm{K}$ - negative control; $\mathrm{K}+$ positive control.

\subsection{Prevalence of EHP disease}

The results showed two positive samples of EHP from ponds four and six. From the formula, the prevalence of the disease was $16.7 \%$ for both shrimp ponds four and six. The samples from ponds one, two, 
three, and five gave EHP negative results (Table 1). The physicochemical water parameters results showed that pond 4 and pond 6 had a range of $1 \mathrm{mg} / \mathrm{l}$ to $1.2 \mathrm{mg} / 1$ of ammonia and nitrite, which were higher than the rest of the ponds ranging from $0.2 \mathrm{mg} / 1$ to $0.5 \mathrm{mg} / \mathrm{l}$. The higher deviation of ammonia and nitrite might explain EHP's positive results in pond 4 and pond 6 . The results from the prevalence of EHP were in agreement with the results from a previous study that showed that ammonia and nitrite accumulation might impact shrimp production by reducing survival, growth performance, and damage of hepatopancreases of L. vannamei, which provides the chance for the opportunistic pathogen like EHP to infect the shrimp (Han et al., 2017).

A growth variation of the shrimp stocked in the same period was observed in this study (Figure $1 \mathrm{~A}$, B). There was an appearance of pale white color in the cephalothorax of the shrimp and hepatopancreas were shrunken (Figure $1 \mathrm{~A}$ ). The observation made in this study agreed with the study of Rajendran et al. (2016) which stated that EHP causes severe growth retardation of the shrimps. EHP affects the shrimp's hepatopancreas causing severe necrosis seen by the sloughing of tubular hepatopancreases epithelial cells and they reported to accumulate the spores in the tubular lumen of shrimps (Aranguren et al., 2017). In another study, Tang et al. (2017) reported that EHP is often accompanied by other opportunistic pathogens, such as Vibrio spp. which colonizes the hepatopancreases after the slough damage of cells done by EHP. The study also stated that the susceptibility of acute hepatopancreatic necrosis disease (AHPND) and Vibrio-associated septic hepatopancreatic necrosis (SHPN) is higher when the shrimp is infected with EHP. According to Tangprasittipap et al. (2013), EHP could be associated with farmed based management practices, including contamination with infected shrimps or poor management of physicochemical water parameters. To better grasp EHP's leading source in these ponds, a screening survey that engages many ponds would give a better understanding.

\subsection{Physicochemical water parameters}

Ponds 4 and 6 showed a notable difference from other ponds (Table 2). The dissolved oxygen at pond 4 and pond 6 was the lowest of about $3.8 \mathrm{mg} / \mathrm{ml}$ and 3.7 $\mathrm{mg} / \mathrm{ml}$ respectively. Ponds $1,2,3$, and 5 had dissolved oxygen ranges between $4 \mathrm{mg} / \mathrm{ml}$ to $4.2 \mathrm{mg} / \mathrm{ml}$. It was observed that ponds 4 and 6 had fewer aerators compared with other ponds which might explain the low dissolved oxygen to pond 4 and pond 6 . Aeration in superintensive ponds helps to supply and diffuse the oxygen from the air into the water, it also helps in circulating the water, food and makes the water column clean. The low dissolved oxygen affected the immune system of shrimps. Flegel (1998) stated that shrimp's phagocytic activity reduced to $28.3 \%$ for oxygen-depleted shrimps from the control group, which were $34.7 \%$. The study also reported that the higher maintenance of oxygen led to an increase in disease resistance.

The temperature was $29^{\circ} \mathrm{C}$ in ponds $1,2,4$, and 6 , while it was $28.5^{\circ} \mathrm{C}$ in ponds 3 and 5 . The temperature difference might be due to the difference in the location of the pond with different weather conditions. According to Food and Agriculture Organization (FAO,1986), water quality parameters influence the normal physiology of shrimps. Temperature influences the rate of biological reaction, as the temperature increase also the rate of biological reaction increases. Based on Fayer (2004) microsporidians depend on temperature. Microsporidians can remain inactive in low temperatures at $30 \%$ artificial seawater.

Pond 4 and 6 had the lowest $\mathrm{pH}$ of 6.8 , while the rest ponds ranged from 7 to 7.5 . $\mathrm{pH}$ has effects on physiology and the immunity of the shrimps. The exoskeleton of the shrimps is made of calcium carbonate which reacts with the acid in the water and makes the exoskeleton soft and easy for pathogenic attack (Furtado et al., 2015). The factors for $\mathrm{pH}$ variation in shrimp aquaculture were studied by Luna (2017).

The higher water salinity was recorded in pond 4 and 6 which were $19 \mathrm{ppt}$ and $18 \mathrm{ppt}$, respectively, while the other pond had water salinity 17 ppt changed in salinity levels affected the growth, physiology, and survival of the shrimps, which made it vulnerable to pathogenic infection (Bøuf and Payan, 2001).

The nitrate concentration was higher at ponds 4 and $6(20 \mathrm{mg} / \mathrm{ml})$, while the remaining ponds had nitrate concentrations ranged from $10 \mathrm{mg} / \mathrm{ml}$ to $15 \mathrm{mg} /$ $\mathrm{ml}$. Nitrate is one of nitrogenous waste which includes ammonia and nitrite. Their harmful nitrogenous waste which should be kept low at all time during shrimp farming (Furtado et al., 2015). Nitrate is reported to cause gills abnormalities, circular dark lesions on the carapace of the shrimp, and generally reducing shrimp health which makes it vulnerable to EHP.

The nitrite concentration was lower at ponds 1,2 , 3 , and $5(0.3 \mathrm{mg} / \mathrm{ml}, 0.5 \mathrm{mg} / \mathrm{ml}, 0.2 \mathrm{ml} / \mathrm{ml}$, and $0.5 \mathrm{mg} /$ $\mathrm{ml}$ respectively) while it was higher in pond 4 and 6 $(1 \mathrm{mg} / \mathrm{ml}$ and $1.2 \mathrm{mg} / \mathrm{ml})$. The ammonia concentration was higher at pond 4 and $6(1.2 \mathrm{mg} / \mathrm{ml}$ and $1 \mathrm{mg} / \mathrm{ml}$, respectively), while it was $0.5 \mathrm{mg} / \mathrm{ml}$ at pond $1,2,3$, and 5. Other studies have reported the effect of ammonia 
Table 1. EHP prevalence estimated from the PCR test results

\begin{tabular}{|c|c|c|c|c|}
\hline Pond No. & Total sample & $\begin{array}{l}\text { Number of the } \\
\text { positive sample }\end{array}$ & Results & $\begin{array}{l}\text { Prevalence of EHP \% = Number } \\
\text { of positive sample / total sample }\end{array}$ \\
\hline 1. & 6 & 0 & Negative & 0 \\
\hline 2. & 6 & 0 & Negative & 0 \\
\hline 3. & 6 & 0 & Negative & 0 \\
\hline 4. & 6 & 1 & $\begin{array}{c}\text { Positive EHP (Enterocytozoon } \\
\text { hepatopenaei) }\end{array}$ & 16.7 \\
\hline 5. & 6 & 0 & Negative & 0 \\
\hline 6. & 6 & 1 & $\begin{array}{c}\text { Positive EHP (Enterocytozoon } \\
\text { hepatopenaei) }\end{array}$ & 16.7 \\
\hline
\end{tabular}

Table 2. Data of physicochemical water parameter

\begin{tabular}{lccccccc}
\hline Pond No. & DO (mg/L) & Temperature $\left({ }^{\mathbf{0}} \mathbf{C}\right)$ & $\mathbf{p H}$ & $\begin{array}{c}\text { Salinity } \\
(\mathbf{p p t})\end{array}$ & $\begin{array}{c}\text { Nitrate } \\
(\mathbf{m g} / \mathbf{L})\end{array}$ & $\begin{array}{c}\text { Nitrite } \\
(\mathbf{m g} / \mathbf{L})\end{array}$ & $\begin{array}{c}\text { Ammonia } \\
(\mathbf{m g} / \mathbf{L})\end{array}$ \\
\hline 1 & 4.2 & 29 & 7.5 & 17 & 15 & 0.3 & 0.5 \\
2 & 4.1 & 29 & 7.2 & 17 & 10 & 0.5 & 0.5 \\
3 & 4.2 & 28.5 & 7 & 17 & 15 & 0.2 & 0.5 \\
4 & 3.8 & 29 & 6.8 & 19 & 20 & 1.0 & 1.2 \\
5 & 4.0 & 28.5 & 7.5 & 17 & 15 & 0.5 & 0.5 \\
6 & 3.7 & 29 & 6.8 & 18 & 20 & 1.2 & 1.0 \\
\hline
\end{tabular}

Table 3. Correlation (r) summary between the ammonia and nitrite concentration with the prevalence of EHP diseases in Litopeneaus vannamei

\section{EHP}

\begin{tabular}{llll} 
& Pearson Correlation & Sig. (2-tailed) & N \\
\hline Ammonia & $0.980 * *$ & 0.001 & 6 \\
Nitrite & $0.943 * *$ & 0.005 & 6 \\
\hline
\end{tabular}

Note; **. Correlation is significant at the 0.01 level (2-tailed); $\mathrm{N}$ - the total number of the sample; Dependent variable is the prevalence of EHP.

Table 4. Regression analysis model to summarize the relationship of EHP prevalence with the ammonia and nitrite concentration

\begin{tabular}{lcccc}
\hline Variable & B-coefficients & $\boldsymbol{\beta}$ & $\mathbf{t}$ - values & $\begin{array}{c}\text { P (significance } \\
\text { level) }\end{array}$ \\
\hline Constant value for Ammonia & -13.14 & & -6.36 & 0.003 \\
Ammonia & 26.72 & 0.98 & 9.8 & 0.001 \\
\hline Constant value Nitrite & -7.02 & & -2.73 & 0.053 \\
Nitrite & 20.36 & 0.94 & 5.66 & 0.005 \\
\hline
\end{tabular}

Note; R-squared for Ammonia = 0.960: R squared for Nitrite $=0.889$; Dependent variable is prevalence of EHP 
and nitrite due to their toxicity reduce hemocytes cells production (Liu et al., 2020) weaken the immune system, cytoskeleton remodeling, and destruct antioxidative system and metabolic pathways in L. vannamei (Xiao et al., 2019). Other studies stated that nitrite and ammonia cause physiological instability in crustaceans hemolymph (Waikhom, 2017; Gomes et al., 2016). In the present study, ponds $1,2,3$, and 5 tested negative for EHP, and the ammonia and nitrite levels were lower than $1 \mathrm{mg} / \mathrm{ml}$. In ponds 4 and 6 , the ammonia and nitrite concentrations were higher than $1 \mathrm{mg} / \mathrm{ml}$. The present study agrees with Gomes et al. (2016) which stated that the safe concentration for ammonia and nitrite is estimated to be $0.834 \mathrm{mg}$ TAN/L and $0.328 \mathrm{mg} \mathrm{NO} 2-$ $\mathrm{N} / \mathrm{L}$ for better growth and survival of the shrimps.

\subsection{The Relationship between the ammonia and nitrite concentration with the prevalence of EHP infections in Litopenaeus vannamei}

EHP showed a strong significant positive correlation with ammonia $(r=0.980)$ of $p<0.001$. It also showed a strong positive significant relationship with nitrite $(r=0.943, p<0.001)$ (Table 3$)$. This study suggests that it is important to monitor and manage shrimp ponds in intensive aquaculture to control the spread of EHP infections. According to Thitamadee et al. (2016), poor management and low biosecurity measures led to the EHP spread resulting in slower growth and fewer returns.

Significant regression analysis for ammonia was carried out with the result of $\mathrm{f}=96, \mathrm{p}<0.001$, with an $\mathrm{R}^{2}$ of 0.960 . It was found that EHP was increased by $26.27 \%$ for each increase in $1 \mathrm{mg} / 1$ of ammonia (Table 4). Based on Liang et al., (2016), ammonia exposure 20 mg TAN/L induced stress factors and led to apoptosis of cells in the hepatopancreas. This condition makes the shrimp vulnerable to pathogenic infection including EHP. A simple linear regression was also calculated to predict EHP infection based on nitrate concentration in the ponds. The simple regression analysis showed $\mathrm{f}$ $=32.038(\mathrm{p}<0.001)$ with an $\mathrm{R}^{2}$ of 0.889 for nitrite. It was also found that EHP was increased by $20.34 \%$ for each increase in $1 \mathrm{mg} / \mathrm{l}$ of nitrite (Table 4). The results were consistent with Ariadi et al. (2019) who stated that nitrite has a high impact on the growth rate and physiology of the shrimps.

\section{Conclusion}

Ammonia and nitrite concentration could influence the prevalence of EHP infection to the shrimps. This study concluded that there was a strong correlation between ammonia and nitrite concentration with the prevalence of EHP infection. The concentration of over $1 \mathrm{mg} / 1$ of ammonia and nitrite could influence EHP infection prevalence in the super-intensive shrimp farms. Despite the detection of EHP infection, the infection source was unknown in these super-intensive ponds. It is recommended to investigate the source of this EHP infection.

\section{Acknowledgment}

The authors would like to thank the Indonesia Ministry of Research, Technology, and Higher Education for their funding contribution through their KNB scholarship.

\section{Authors Contributions}

All authors have contributed to the final manuscript as follows, Anord; collected the data and wrote the original manuscript. Gunanti; designed, supervised, reviewed and edited the research and also managed project administration. Nunuk; reviewed, edited, and supervised the research. Mwendolwa; proofread, reviewed, and edited the final manuscript.

\section{Conflict of Interest}

The authors declare that they have no conflict of interest.

\section{Funding Information}

This work was supported by the Indonesia Ministry of Research, Technology, and Higher Education through a KNB scholarship research grant.

\section{References}

Alfiansah, Y. R., Peters, S., Harder, J., Hassenrück, C., \& Gärdes, A. (2020). Structure and co-occurrence patterns of bacterial communities associated with white feces disease outbreaks in Pacific white-leg shrimp Penaeus vannamei aquaculture. Scientific Reports, 10(1):1-14.

Anjaini, J., Agustin, I., \& Bayu, I. (2018). Histopathological in gills, hepatopancreas and gut of white shrimp (Litopenaeus vannamei) infected white feces disease (WFD). Research Journal of Life Science, 5(3):183-194.

Aranguren, L. F., Han, J. E., \& Tang, K. F. J. (2017). Enterocytozoon hepatopenaei (EHP) is a risk factor for acute hepatopancreatic necrosis disease (AHPND) and septic hepatopancreatic necrosis (SHPN) in the Pacific white shrimp Penaeus vannamei. Aquaculture, 471:37-42.

Ariadi, H., Fadjar, M., Mahmudi, M., \& Supriatna. 
(2019). The relationships between water quality parameters and the growth rate of white shrimp (Litopenaeus vannamei) in intensive ponds. $A A C L$ Bioflux, 12(6):2103-2116.

Aydin, A., Ercan, Ö., \& Taşcioğlu, S. (2005). A novel method for the spectrophotometric determination of nitrite in water. Talanta, 66(5):1181-1186.

Biju, N., Sathiyaraj, G., Raj, M., Shanmugam, V., Baskaran, B., Govindan, U., Kumaresan, G., Kasthuriraju, K. K., \& Chellamma, T. S. R. Y. (2016). High prevalence of enterocytozoon hepatopenaei in shrimps Penaeus monodon and Litopenaeus vannamei sampled from slow growth ponds in India. Diseases of Aquatic Organisms, 120(3):225-230.

Bœuf, G., \& Payan, P. (2001). How should salinity influence fish growth? Comparative Biochemistry and Physiology - C Toxicology and Pharmacology, 130(4):411-423.

Caro, L.F. A., Mai, H.N., Pichardo, O., Cruz-Flores, R., Hanggono, B., \& Dhar, A.K. (2020). Evidences supporting Enterocytozoon hepatopenaei association with white feces syndrome in farmed Penaeus vannamei in Venezuela and Indonesia. Diseases of Aquatic Organisms, 141:71-78.

Duan, Y., Liu, Q., Wang, Y., Zhang, J., \& Xiong, D. (2018). Impairment of the intestine barrier function in Litopenaeus vannamei exposed to ammonia and nitrite stress. Fish and Shellfish Immunology, 78: 279-288.

Fayer, R. (2004). Infectivity of microsporidia spores stored in seawater at environmental temperatures. The Journal of Parasitology, 90(3):654-657.

FAO. (1986). Shrimp culture and pond management. http://www.fao.org/3/ac210e/AC210E09.htm

Flegel, T. W. (1998, November). Advances in Shrimp Biotechnology. Paper presented at Proceedings to the Special Session on Shrimp Biotechnology. 5th Asian Fisheries Forum, 147-149. Chiengmai, Thailand.

Furtado, P. S., Fugimura, M. M. S., Monserrat, J. M., Souza, D. M., Garcia, L. de O., \& Wasielesky, W. (2015). Acute effects of extreme $\mathrm{pH}$ and its influences on the survival and biochemical biomarkers of juvenile White Shrimp, Litopenaeus vannamei. Marine and Freshwater Behaviour and Physiology, 48(6):417-429.

Furtado, P. S., Campos, B. R., Serra, F. P., Klosterhoff,
M., Romano, L. A., \& Wasielesky, W. (2015). Effects of nitrate toxicity in the Pacific white shrimp, Litopenaeus vannamei, reared with biofloc technology (BFT). Aquaculture International, 23(1):315-327.

Gomes, R. S., de Lima, J. P. V., Cavalli, R. O., \& Correia, E. de S. (2016). Acute Toxicity of Ammonia and Nitrite to Painted River Prawn, Macrobrachium carcinus, Larvae. Journal of the World Aquaculture Society, 47(2):239-247.

Gutiérrez-Salazar, G. J., Molina-Garza, Z. J., Hernández-Acosta, M., García-Salas, J. A., Mercado-Hernández, R., \& Galaviz-Silva, L. (2011). Pathogens in Pacific white shrimp (Litopenaeus vannamei Boone, 1931) and their relationship with physicochemical parameters in three different culture systems in Tamaulipas, Mexico. Aquaculture, 321(1-2):34-40.

Han, S., Wang, B., Wang, M., Liu, Q., Zhao, W., \& Wang, L. (2017). Effects of ammonia and nitrite accumulation on the survival and growth performance of white shrimp Litopenaeus vannamei. Invertebrate Survival Journal, 14(1):221-232.

Hanggono, B., Lestari,Y. N., Fatmawati, Waluya, J., \& Yuli, T. E. (2019). Deteksi cepat Enterocytozoon hepatopenaei (EHP) pada udang vaname (Penaeus vannamei). Jurnal Perekayasaan Budidaya Air Payau dan Laut, 14:35-40.

Jaroenlak, P., Sanguanrut, P., Williams, B. A. P., Stentiford, G. D., Flegel, T. W., Sritunyalucksana, K., \& Itsathitphaisarn, O. (2016). A nested PCR assay to avoid false positive detection of the microsporidian Enterocytozoon hepatopenaei (EHP) in environmental samples in shrimp farms. PLOS One, 11(11): e0166320.

Karthikeyan, K., \& Sudhakaran, R. (2020). Exploring the potentiality of Artemia salina to act as a reservoir for microsporidian Enterocytozoon hepatopenaei of penaeid shrimp. Biocatalysis and Agricultural Biotechnology, 25, 101607.

Karthikeyan, Kesavan, \& Sudhakaran, R. (2019). Experimental horizontal transmission of Enterocytozoon hepatopenaei in post-larvae of whiteleg shrimp, Litopenaeus vannamei. Journal of Fish Diseases, 42(3):397-404.

Liao, I. C., \& Chien, Y. (2011). The Pacific white shrimp, Litopenaeus vannamei, in Asia: The World's Most Widely Cultured Alien Crustacean. (pp. 489-519). 
In In the Wrong Place - Alien Marine Crustaceans: Distribution, Biology and Impacts. New York: Spinger.

Liang, Z., Liu, R., Zhao, D., Wang, L., Sun, M., Wang, M., \& Song, L. (2016). Ammonia exposure induces oxidative stress, endoplasmic reticulum stress and apoptosis in hepatopancreas of pacific white shrimp (Litopenaeus vannamei). Fish and Shellfish Immunology, 54: 523-528.

Liu, C. H., \& Chen, J. C. (2004). Effect of ammonia on the immune response of white shrimp Litopenaeus vannamei and its susceptibility to Vibrio alginolyticus. Fish and Shellfish Immunology, 16(3):321-334.

Liu, F., Li, S., Yu, Y., Sun, M., Xiang, J., \& Li, F. (2020). Effects of ammonia stress on the hemocytes of the Pacific white shrimp Litopenaeus vannamei. Chemosphere, 239:124759.

Luna, G. (2017). Effects of pH, Alkalinity, and hardness on growth \& Survivals of Vannamei shrimp in Aquaculture. Elsevier.

Mahasri, G., Hidayat, T., \& Sudarno. (2019). Prevalence and intensity of ectoparasites in Pacific white shrimp (Litopenaeus vannamei) seeds from a pond and hatchery. IOP Conference Series: Earth and Environmental Science, 236(1).

Morris, A. W., \& Riley, J. P. (1963). The determination of nitrate in sea water. Analytica Chimica Acta, 29(C), 272-279.

Nguyen, T. A. T., Nguyen, K. A. T., \& Jolly, C. (2019). Is super-intensification the solution to shrimp production and export sustainability?. Sustainability, 11(19), 1-22.

Pamenang, G. D., Sulmartiwi, L., Mahasri, G., Rahayu, N. D., \& Angwarmas, B. (2020). Inventory of ectoparasites in pacific white shrimp (Litopenaeus vannamei) that cultivated with high density. IOP Conference Series: Earth and Environmental Science, 441(1).

Rajendran, K. V., Shivam, S., Praveena, E. P., Rajan, J. S., Kumar, T.S., Avunje, S., Jagadeesan, V., Prasad Babu, S. V. A. N. V., Pande, A., Krishnan, A. N., Alavandi, S. V., \& Vijayan, K. K. (2016). Emergence of Enterocytozoon hepatopenaei (EHP) in farmed Penaeus (Litopenaeus) vannamei in India. Aquaculture, 454(2016), 272-280.

Rubel, H., Woods, W., Pérez, D., Unnikrishnan, S., Felde, A. M. Z., Zielcke, S., Lidy, C. \& Lanfer,
C. (2019). A Strategic Approach to Sustainable Shrimp Production in Thailand: The Case for Improved Economics and Sustainability. Boston: Boston Consulting Group.

Sivakumar, S., Vimal, S., Abdul Majeed, S., Santhosh Kumar, S., Taju, G., Madan, N., Rajkumar, T., Thamizhvanan, S., Shamsudheen, K. V., Scaria, V., Sivasubbu, S., \& Sahul Hameed, A. S. (2018). A new strain of white spot syndrome virus affecting Litopenaeus vannamei in Indian shrimp farms. Journal of Fish Diseases, 41(7):1129-1146.

SNI. (2000). Batas maksimum cemaran mikroba dan batas maksimum residu dalam bahan makanan asal hewan. Standar Nasional Indonesia No: 01-63662000. 16 p.

Sumini, S., \& Kusdarwati, R. (2020). The discovery of Vibrio harveyi on Litopenaeus vannamei infected white feces disease in Situbondo, East Java. Jurnal Perikanan Universitas Gadjah Mada, 22(1), 9-18.

Tang, K. F. J., Aranguren, L. F., Piamsomboon, P., Han, J. E., Maskaykina, I. Y., \& Schmidt, M. M. (2017). Detection of the microsporidian Enterocytozoon hepatopenaei (EHP) and Taura syndrome virus in Penaeus vannamei cultured in Venezuela. Aquaculture, 480: 17-21.

Tang, K. F. J., Han, J. E., Aranguren, L. F., WhiteNoble, B., Schmidt, M. M., Piamsomboon, P., Risdiana, E., \& Hanggono, B. (2016). Dense populations of the microsporidian Enterocytozoon hepatopenaei (EHP) in feces of Penaeus vannamei exhibiting white feces syndrome and pathways of their transmission to healthy shrimp. Journal of Invertebrate Pathology, 140: 1-7.

Tang, K., Pantoja, C., Redman, R. M., Han. J.E., Tran L., \& Lightner, D.V. (2015). Development of in situ hybridization and PCR assays for the detection of Enterocytozoon hepatopenaei (EHP), a microsporidian parasite infecting penaeid shrimp. Journal of Invertebrate Pathology, 130:37-41.

Tangprasittipap, A., Srisala, J., Chouwdee, S., SombooTang, K. F. J., Pantoja, C. R., Redman, R. M., Han, J. E., Tran, L. H., \& Lightner, D. V. (2015). Development of in situ hybridization and PCR assays for the detection of Enterocytozoon hepatopenaei (EHP), a microsporidian parasite infecting penaeid shrimp. Journal of Invertebrate Pathology, 130:37-41.

Tangprasittipap, A., Srisala, J., Chouwdee, S., Somboon, M., Chuchird, N., Limsuwan, L., Srisuvan T., 
Flegel, T. W., \& Sritunyalucksana, K. (2013). The microsporidian Enterocytozoon hepatopenaei is not the cause of white feces syndrome in whiteleg shrimp Penaeus (Litopenaeus) vannamei. BMC Veterinary Research, 9:139.

Thitamadee, S., Prachumwat, A., Srisala, J., Jaroenlak, P., Salachan, P. V., Sritunyalucksana, K., Flegel, T. W., \& Itsathitphaisarn, O. (2016). Review of current disease threats for cultivated penaeid shrimp in Asia. Aquaculture, 452:69-87.

Tourtip, S., Wongtripop, S., Stentiford, G. D., Bateman, K. S., Sriurairatana, S., Chavadej, J., Sritunyalucksana, K., \& Withyachumnarnkul, B. (2009). Enterocytozoon hepatopenaei sp. nov. (Microsporida: Enterocytozoonidae), a parasite of the black tiger shrimp Penaeus monodon (Decapoda: Penaeidae): Fine structure and phylogenetic relationships. Journal of Invertebrate Pathology, 102(1):21-29.
Waikhom, S. (2017). Effect of ammonia and nitrite toxicity on Pacific White Shrimp Litopenaeus vannamei in culture systems. Master Thesis, 15055:87.

Xiao, J., Li, Q. Y., Tu, J. P., Chen, X. L., Chen, X. H., Liu, Q. Y., Liu, H., Zhou, X. Y., Zhao, Y. Z., \& Wang, H. L. (2019). Stress response and tolerance mechanisms of ammonia exposure based on transcriptomics and metabolomics in Litopenaeus vannamei. Ecotoxicology and Environmental Safety, 180:491-500.

Zhao, M., Yao, D., Li, S., Zhang, Y., \& Aweya, J. J. (2020). Effects of ammonia on shrimp physiology and immunity: a review. Reviews in Aquaculture, 12(4):2194-2211.

Zitomer, F., \& Lambert, J. L. (1962). Spectrophotometric determination of ammonia as trichloramine. Analytical Chemistry, 34(13):1738-1740. 